\title{
Having Good Speaking English through Tik Tok Application
}

\author{
Destia Herlisya $^{1 凶}$, Purna Wiratno $^{2}$ \\ ${ }^{12}$ STKIP PGRI Bandar Lampung, Lampung, Indonesia \\ 凶 email: destia_herlisya@stkippgribl.ac.id ${ }^{1}$,purna_wiratno@stkippgribl.ac.id ${ }^{2}$
}

\section{Received: \\ 9 January 2022}

Revised:

10 January 2022

Accepted:

11 January 2022

Published:

14 January 2022

\begin{abstract}
Tik tok is one of the most loved apps in the millennial era. The Tik Tok application is an application to create and share various short videos in vertical format, which is played by simply scrolling the screen up or down. Tik Tok users are increasing every day, especially during the pandemic era. In 2020, as of October Tik Tok reached 2 billion downloads worldwide. This application originating from China is widely downloaded by social media users to relieve boredom when they have to stay at home. This study aims to improve students' speaking skills through the Tik Tok application. The subjects of this study were 20 students of the third semester in English education major at STKIP PGRI Bandar Lampung. The method used is descriptive quantitative method using classroom action research techniques. Based on the result, the improvement of students' learning activities showed mean score of students' learning activities in pre cycle is 68.88 , in cycle I was 69 with the criteria was less active. While, the mean score of students' learning activities in cycle II was 76.75 with the criteria were quite active. So, the improvement of students' learning activities the first cycle to the second cycle was 7.75 point. From analyzing data, it could be concluded that classroom action research by using Tik Tok App improved students' learning activities and students' speaking skill.
\end{abstract}

Keywords: Application, Learning Media, Speaking, Tik Tok.

\section{INTRODUCTION}

The world is changing, whether like it or not, people have to live side by side with the covid 19 pandemic. Since Indonesia started imposing activity restrictions and quarantines in March 2020, the world of education has also been affected. Children are not allowed to go to school, school activities are abolished. Students and teachers must undergo online learning, educators must be ready to face these changes. Fortunately, current technological developments continue to grow rapidly, making it easier for us to innovate and use learning media. According to Zaitun, Hadi and Indriyani (2021), "learning media has a meaning as a learning resource that develops in accordance with the development of learning teachnology and various forms, from audio and visual to audio visual." This is very beneficial for us because there are many learning media that can be used for teaching, especially for language learning. 
Learning language has become very important from the past until now. According to Rabiah, "through language, we can show our perspective, our understanding of the matter, the origin of the nation and our state, our education level, and even our character". Through language, people can communicate with the outside world, and without any boundaries. Mastering English is a must for millennials, English itself is an international language which is the main language when communicating. Almost in all sectors, such as business, education, national defense, economy and development that use English as a communication bridge with the outside world. English in Indonesia is a foreign language that is learned in schools from elementary school to university level. However, there are still many people who think English is a burden and a scourge for them. The demands of the world of work now often include English as one of the skills that must be possessed.

Speaking is one of the most difficult skills that has to be faced by the students. Why? Because, students tend to be shy to speak a foreign language when they feel they do not master the language, even though they are in the English education department. In addition, the researchers also found the problem that the lack of vocabulary mastery and lack of practice also made speaking difficult for most students. This difficulty reduces the motivation and interest of students to continue to spur themselves to be fluent in English. Many students are good at writing English, but become freezing when it comes to speak English. Based on Pratiwi (2021), "there are six important things considered to be useful that someone can be more fluent and brave in speaking. They are confidence, fluency \& accuracy, finding the right words, showing where we are going, keeping the listeners interested and sounding natural."

The educational process greatly affects the success of education in achieving its goals so this requires special attention. The educators must pay attention to how to disseminate knowledge that can generate activity, creativity, mentality, motivation and foster moral values. Learning media is one of many things that can affect learning outcomes. There were four main purposes for using social media applications, which are entertainment, socialization, in formativeness and academic (Yang, 2020). It means that the social media can be used as language learning media.

The use of appropriate learning media can also improve students' speaking skills. Students tend to like new things that match their daily lives, for example, using social media applications. The use of social media itself in the field of education is not a new thing. Many researchers have used social media applications as learning media, for example, Herlisya \& Alfiawati (2019) who used Instagram as a medium for teaching English writing skill, Nurmy (2017) using Facebook as a medium in learning English as a foreign language, Kumar Sah (2015) using twitter as a language tool in the ESL/EFL classroom, and Pratiwi, Ufairah and Sopiah (2021) used Tik Tok as media for learning english pronunciation.

The Tik Tok application is a social media application that can be downloaded via the App Store and Google Play Store. Originating from China, tiktok is a Chinese social network and music video platform launched in September 2016. This app allows users to create their own short music videos. In China this application is 
known as Dou Yin, but because it is considered less familiar to people outside China, the name was changed to TIK TOK. In Indonesia itself, this application was opposed by various parties because it was considered to often contain negative content. However, since the pandemic hit, this application has been downloaded a lot to reduce the stress of having to stay at home. Over time, many content creators upload educational videos, scientific videos, and various other creative videos, therefore Tik Tok is an application that can be used as a learning medium as long as it is used properly. This is supported by Pratiwi (2021) in her journal that stated that, "The research shows that the respondents had a positive attitude toward tiktok application used it as an English language learning strategy to help and enhance literacy and speaking skills." The previous researcher in using Tik Tok App as a learning medium is Zaitun (2021). She said that, "the application with the use of appropriate methods and techniques can be used as an interactive learning medium that can improve students' speaking ability".

Speaking itself is our way communicate and interact with other people. When a person speaks, he can convey his mind, his purpose, and also the meaning. When a person speaks, the other person will receive the information and absorb it. So there is a process of good communication and interaction. However, when students speak English in front of the class or in the school environment, they often do not find an audience who is willing to give feedback, or even responds. This is because the image of the famous English language is difficult for most of Indonesian.

Speaking English through Tik tok makes students have their own audience. They can be more confident because there will be people watching their videos, and give them 'like'. Once they get a lot of 'likes' students will be even more excited and keep trying to make better videos. Obviously, other than to improve speaking skill, Tik tok also sharpens students' creativity.

The procedures of teaching speaking using Tik Tok App is:

1. The students have to make a tik tok account.

2. The researchers and the students follow each other account.

3. The researchers ask the students to watch some videos in Tik Tok (the video is about education, place, dancing, cooking, famous people, news and etc).

4. After the students watch the videos, the researchers asked the students to describe what is it about.

5. The researchers ask the students to remake the content by making their own version. 6 . The students can create and edit their own video however they like, and adjust to their style.

6. Other students must also respond by asking questions or comments in their friend's account.

7. Each students can give 'like' to their friend's video if they like it as a sign of appreciation.

The objectives of the research are; first to describe whether the using of Tik Tok App improves students' learning activity in learning speaking, and second, to describe whether the using of Tik Tok App improves students' speaking skills. There 
are two hypotheses in this research, they are: 1. Tik tok app improves the students' learning activities in learning speaking, 2. Tik tok app improves the students' learning speaking skill.

\section{METHOD}

This research used classroom action research to improve students' speaking skill through Tik Tok App. The subject of the research was the English education students of at STKIP PGRI Bandar Lampung in 2021/2022. It consists of 20 students. Classroom action research is used to improve the learning process in the classroom. The ultimate goal of implementing classroom action research is to produce an improvement in the learning process. According to Tomal (2010) action research is systematic process in solving educational problems and making improvements. Purrohman (2011) stated that Classroom Action Research is an alternative research application that easily conducted during teaching and learning processes. The research was done by two cycles, in cycle I there are four meetings, as well as cycle II. The procedures are planning, action, observation and reflection (Taggart, 2013). In planning, the researchers arranged for doing something, like identified students' problem in speaking, then arranged steps of teaching plan and prepared for it. In action, it was a process when the plan was being done. In this step, researchers did the teaching and learning process by using Tik tok app. Observation was aimed to get the information of action. The researchers observed the development of students in learning activity in speaking skill through observation sheet and field note. Reflection was the feedback process of all the activities. The method used to analyze the qualitative data was the descriptive qualitative method.

The procedures in collecting the data are observation and test. In observation, the researchers make observation sheet to collect the data by looking the activities performed by students during the learning process. The second is test. The researchers conduct the test to sharpen the students' speaking skill. The test is the student must present or re-tell the video he has watched on Tik tok in front of the class. To find mean score of students' learning activities and to find the mean score of students' speaking skill, the researchers used following formula:

$\bar{x}=\frac{\sum x}{n}$

(Sudjana, 2005)

$\bar{X} \quad=$ mean score of students learning activities

$\sum x=$ sum of mean score of all students

$n \quad=$ total number of students

To find of students' minimum mastery criterion, the researchers used the formula (Sudjana, 2005) below to analyze the data:

$\mathrm{X} \%=\frac{\sum \text { fixi }}{\sum f i} \times 100 \%$ 
$\mathrm{X} \% \quad=$ the percentage of the students who have passed

$\sum$ fixi $=$ the total students who have passed

$\sum f i=$ the total of the entire students

The researchers then used the criteria to know the effectiveness of learning outcome by Aqib (2009):

Table 1. The Criteria of Students' Learning Outcome

\begin{tabular}{|c|c|c|}
\hline No & Learning Outcome & Category \\
\hline 1 & $86-100 \%$ & Excellent \\
\hline 2 & $71-85 \%$ & High \\
\hline 3 & $56-70 \%$ & Fair \\
\hline 4 & $41-55 \%$ & Poor \\
\hline 5 & $<40 \%$ & Very Poor \\
\hline
\end{tabular}

\section{FINDINGS AND DISCUSSION}

The research was conducted by using a classroom action research with using Tik Tok App as a medium in learning speaking. This research consisted of two cycles and each cycles has three meetings. Planning, acting, observing and reflecting were the four steos that need to be run in this research. The results of the quantitative data show that the use of the Tik Tok application can improve English speaking skills of students majoring in English education at STKIP PGRI Bandar Lampung. This can be seen from the average results achieved by students at the time of given a test. Based on the result, in cycle I, the students' learning activities showed mean score was 69 with the criteria was less active. The mean score of students' learning activities in cycle II was 76.75 with the criteria were quite active. The improvement of the students' learning activities from the 1st cycle to the 2 nd cycle was 7.75 point. The improvement of students' speaking skill showed mean score in pre-cycle was 68.88 , there was only one student or $20 \%$ who achieved the target score. The improvement in cycle I was 69. There were 6 students who achieved score above minimum mastery criteria or $30 \%$ and the mean score of cycle II was 76.75 , there were 12 students who achieved score above minimum mastery criteria or $60 \%$.

Table 2. The result of students' learning activity

\begin{tabular}{|c|c|c|}
\hline Cycle I & Cycle II & Improvement \\
\hline Average score & Average score & 7.75 \\
\hline 69.00 & 76.75 & \\
\hline
\end{tabular}

From the table above, it can be concluded that students' learning activities improved from cycle I to cycle II. This because the implementation of using Tik tok as a learning medium is proven to be able to improve students' speaking skills. 


\section{Graphic 1. The Improvement of Students' Learning Activities}

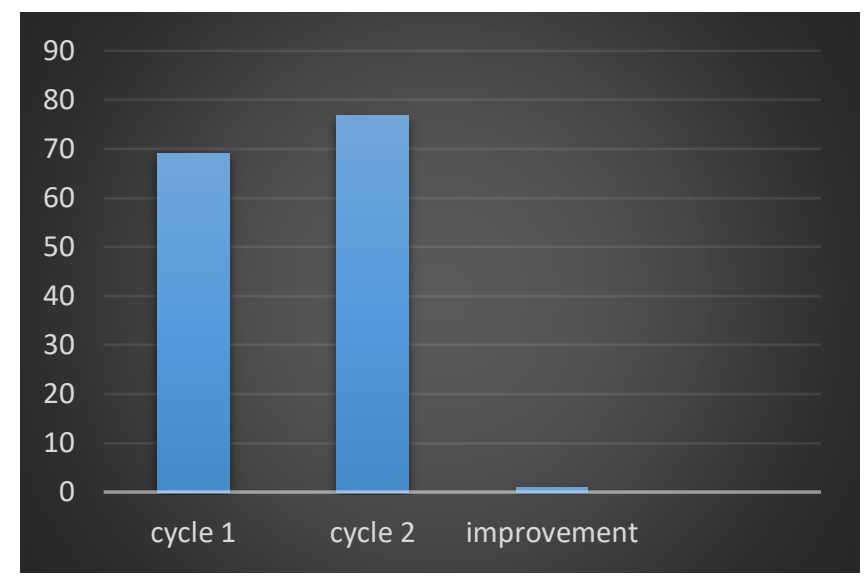

The result below showed that there was an improvement of students' speaking score from pre-cycle, cycle I and cycle II. The mean score of speaking test in pre cycle was 68.88 . In cycle I, the mean score was 69 and in cycle II was 76.75.

Table 3. The result of Students' score in speaking skill

\begin{tabular}{|c|c|c|}
\hline Pre Cycle & Cycle I & Cycle II \\
\hline Mean & Mean & Mean \\
\hline 68.88 & 69.00 & 76.75 \\
\hline
\end{tabular}

Based on the result and analysing the data, it showed that there is an increasing of the students' learning activities. The result in cycle I was $30 \%$, and in cycle II was $60 \%$. The researchers strongly believe that using a Tik tok app can foster students' interest in learning. According to zaitun (2021), the students can use the application of Tiktok in a positive direction. This is also supported by Fahdin (2020) who stated that, "Students show positive feedback of utilizing Tik Tok as their language learning media that the English content videos easy to understand and easy to memorize various vocabularies they found on those videos, like vocabularies about verbs, nouns, etc".

In the first cycle test showed an increase in students' speaking skills when compared to the pre cycle results. The average score obtained by students in English speaking skills in the final test of the first cycle is $30 \%$, this value is still far from the target, which is $60 \%$. Although improvements were found, most of the students still had problems. In addition to using sentence structures that are too simple and incomplete when speaking, they also forget to place the auxiliary verb (to be) according to the subject and time. In addition, the lack of vocabulary mastery affects the students' use of sentence structures, and also affects maximum communication. Students' lack of fluency is caused by feeling nervous and tense when asked to describe a video. Students still need quite a long time to think, especially those related to vocabulary idioms. Students seem to be able to understand the meaning of the conversation, requests, and instructions for questions posed by the researcher at the end of cycle II. It is proven in the understanding indicator 
that an average score of 76.75 was obtained, with twelve students achieved a score above the minimum mastery criteria or $60 \%$.

The use of the Tik Tok application is not only to improve students' speaking skills but also, this application can motivate students to become more confident. Apart from being entertainment, Tik Tok can increase one's creativity. Students will be trained by themselves to be creative people by following trends and editing the content they have created. In addition, Tik Tok is useful for providing information related to various things. Starting from education, scholarships, webinars, make up products, to gossip in cyberspace. The Tik tok application also allows students to make friends and expand their relationship. This has a very good impact, especially for students who tend to be introverted. The use of the Tik tok application can help improve student understanding and facilitate interpretation.

\section{CONCLUSION}

Using Tiktok as a learning medium is the right choice to improve students' speaking skills. This application has features that are up to date so that everyone depends on it. Students will find it easier to absorb English vocabulary faster because they learn through the media they like and usually use. Teachers and lecturers are advised to be able to adapt to the times. The use of tik tok to improve speaking skills not only helps students to improve their speaking skill, but also becomes more interactive. If used properly, this application has many advantages that benefit both teachers and students. Through Tik tok, the learning atmosphere becomes fun, teacher and students can discuss many things, especially things that are familiar to our students. In can be concluded that Tik tok is our students' inseparable friend. This application is also very effective to increase students' confidence. This can be seen from the scores that have been achieved from cycle I to cycle II.

However, as a learning medium, Tik Tok certainly has weaknesses. Students cannot access this application if they do not have internet. The Tik Tok application also often becomes slow if the cellphone or device used is not compatible enough. To overcome this, the teacher must ensure that the internet network in the learning location is strong enough to open this application. Although it has weaknesses, the Tik Tok application is very worthy to be chosen and considered as a learning medium. the tik tok application is a new breakthrough in the world of education and tik tok has a number of benefits that can be developed for the learning process.

\section{REFERENCES}

Fahdin. (2020). Student's Perception Toward The Use Of Tik Tok In Learning English Vocabulary. International Conference Labma Scientific Fair 2020, Yogyakarta

Herlisya, D. \& Alfiawati, R. (2020). The Influence of Instagram's Pictures towards the

Students' Essay Writing Skill. Vol 1 No 2: JETA (Journal of English Teaching and

Applied Linguistic). DOI: https://doi.org/10.2020/jeta.v1i2.592

Kemmis, S., \& Taggart, R. Mc. (2013). The Action Research Planner. Singapore: 
Springer. ISBN: 9789814560672

Kumar Sah, P. (2015). 'Let's tweet to learn English': Using Twitter as a Language Tool in the ESL/EFL Classroom. Vol 2 No 1: Langlit (An International Peer Reviewed Open Access Journal.

Nurmy, A.R. (2017). Facebook as a Medium in English Learning as Foreign Language at IAIN Pontianak. Vol 11 (1) 48-37: At Turats (Jurnal Pemikiran Pendidikan Islam).

Pratiwi, Anggi., Uffairah, Naura. \& Sopiah, R. (2021). Utilizing Tiktok Application as Media for Learning English Pronunciation. Page 372-382: Proceedings International Conference on Education of Suryakancana.

Purrohman, P.S. (2011). Classroom Action Research Alternative Research Activity for Teachers. Uhamka: Jakarta.

Rabiah, Sitti. (2012). Language as a Tool for Communication and Cultural Reality Discloser. International Conference on Media, Communication and Culture 'Rethinking multiculturalism: By UMY Yogyakarta and Univerisiti Sains Malaysia.

Sudjana. (2005). Metode Statistik. Bandung: Tersito.

Tomal, Daaniel R. (2010). Action Research for Educators. Oxford: Rowman \& Littlefield Publishers. ISBN: 9781607096481

Yang, H. (2020). Secondary-school Students' Perspectives of Utilizing Tik Tok for English Learning in and beyond the EFL Classroom. Etss, 162-183.

Zaitun., Hadi, M. \& Indriani, E.D. (2021). TikTok as a Media to Enhancing the Speaking Skills of EFL Student's. Vol 4(1): Jurnal Studi Guru dan Pembelajaran. DOI: https://doi.org/10.30605/jsgp.4.1.2021.525 